\title{
CONFLICT BETWEEN FARMERS AND HERDSMEN ON FOOD STABILITY IN TARABA STATE
}

\author{
Solomon Binga Lezuya (Ph.D.) ${ }^{1}$, Kaka Olusegun Jimoh (Ph.D.) ${ }^{2}$ and \\ Sarki Samuel Msheliza (Ph.D.) ${ }^{3}$
}
${ }^{1}$ Department of Political Science, Faculty of Social Sciences, Rivers State University, Nkpolu-Oroworukwo, Port Harcourt, Rivers State, Nigeria.
Email: lezuyabinga@yahoo.co.uk
${ }^{2}$ Department of Political Science, Faculty of Social Sciences, Rivers State University, Nkpolu-Oroworukwo, Port Harcourt, Rivers State, Nigeria
Email: kakaolusegun74@gmail.com
${ }^{3}$ Department of Political Science, Faculty of Social Sciences, Rivers State University, Nkpolu-Oroworukwo, Port Harcourt, Rivers State, Nigeria
Email: samuelmmsarki@gmail.com

Cite this article: Solomon B. L., Kaka O. J., Sarki S. M. (2021), Conflict Between Farmers and Herdsmen on Food Stability in Taraba State. African Journal of Law, Political Research and Administration 4(1), 1-17. DOI:

10.52589/ajlpra_eggkqfac.

\section{Manuscript History}

Received: 14 March 2021

Accepted: 10 April 2021

Published: 18 April 2021

Copyright $\odot 2020$ The Author(s). This is an Open Access article distributed under the terms of Creative Commons AttributionNonCommercial-

NoDerivatives 4.0 International (CC BY-NC-ND 4.0), which permits anyone to share, use, reproduce and redistribute in any medium, provided the original author and source are credited.
ABSTRACT: One major problem confronting the national peace of Nigeria today is the manifestation of conflicts between farmers and herders in different dimensions across the country. This conflict has spread over wide geographical areas in Nigeria and Taraba State in particular. Therefore, this study was conducted to determine the impact of farmers-herders conflicts on food production, food availability, food stability and food utilization in Taraba state. Three objectives, three research questions and three hypotheses were adopted to guide this study. The study utilized the survey research method and sampled 385 respondents using multistage sampling technique. The data for this study was obtained from both primary and secondary sources. Primary data was generated from a field survey using a structured questionnaire. The study utilized data and infrastructure from multiple policy documents in the State Ministry of Agriculture, Jalingo. Data generated from the field were complemented by extensive review on the farmers-herders conflicts. The data collected were analyzed using a $p$ table, and Percentage and Pearson Correlation was used to test the hypotheses. The study findings revealed that there exists a significant relationship between farmers-herdsmen conflicts and food stability problems in Taraba State; also, there is significant relationship between farmersherdsmen conflicts and food availability in Taraba State, amongst others. The study concluded that herdsmen do not recognize the existence of any boundary in terms of their grazing, coming in hundreds, usually fully armed with modern guns, and they move with thousands of cattle, sparing no farm. Thus, government should establish sustainable cattle ranching in different parts of Taraba State and encourage mediu $m$ techniques in cattle rearing to curb the menace of farmers-herders clashes.

KEYWORDS: Farmers, Herdsmen, Conflict, Food Stability, Taraba State, Nigeria 


\section{INTRODUCTION}

\section{Background of the Study}

The manifestation of conflicts in various dimensions around the globe is one of the major problems facing world and national peace today. Conflicts occur all over the world, from Europe to America, Africa to Asia (Jeony, 2008, p. 56). Nigeria has faced and continues to face widespread violent conflicts of horrific proportions among various groups, cultures, religions, and political classes across the country since the return to democratic rule in 1999. The dimensions, processes, and actors involved in these persistent and widespread conflicts vary significantly.

Momale (2003) established conflicts between resource user groups such as one farming community and another, as well as conflicts between different user groups such as herders and farmers, and foresters and farmers. However, the most common resource dispute in Nigeria is between farmers and herders (Adisa, 2012, p.13). This is owing to the fact that land disputes, especially on grazing fields, account for the majority of the disputes between the two parties. To put it another way, the struggle for control of economically viable resources increases tensions and violent conflicts among farming communities, as well as between herders and crop cultivators. This is not surprising given that land is one of the most essential resources needed for man's complete life. To begin with, all human livelihoods and activities are to some extent dependent on soil, either directly or indirectly. To the various groups that use property, land means different things. For instance, consider the significance and application of land in road construction. Companies for house builders, fishermen, farmers, herders, miners, and manufacturers cannot be the same. They all have different demands and land use requirements for their respective productive services.

Conflict is a common occurrence in plural cultures and can be found in all areas of human endeavour. Human societies tend to be characterised by conflict. It is inevitable, according to Coser (2003, p. 67), and therefore is likely to occur at any time and in any place. Based on scholars' ideological learnings, conflict is characterised in a variety of ways. Conflict, according to Jerry and Jerry (2000, p. 97), is an open clash between individuals or groups within a community or between nations. Conflict, in this context, is a clear and deliberate struggle between individuals or groups pursuing the same objective(s). Conflict may also be described as the involvement of interdependent parties in order to achieve these objectives (ACLED, 2015, p. 45). The term conflict typically refers to a situation in which one identifiable group of human beings in a given setting (whether tribal, racial, linguistic, cultural, religious, socioeconomic, or political) is in conscious opposition to one or more identifiable human groups because these opposing groups are pursuing what appear to be incompatible goals. Farmers and cattle herders have incompatible priorities, which have resulted in a clear and conscious struggle in agriculture. Conflict is described by Ekong (2003, p. 44) as a type of social interaction in which actors seek reward by removing or weakening their rivals. Conflict is described by Fulger $(2009$, p. 9) as the relationship of autonomous people who interpret conflicting goals by interfering with one another in order to achieve those goals. Conflict is described by Giyong (2007, p. 78) as a fight for dominance or control of one individual or group by another in order to subjugate or even remove the opponent.

Farmers and herders have had resource conflicts since the beginning of time. Farmers-herders conflict has remained Nigeria's biggest resource-use conflict, despite its changing nature and 
intensity. Herders and farmers have coexisted for a long time but such coexistence has always been tense because it necessitates a state of rural concern. When livestock is not properly managed and herds wander into cultivated fields, conflict may arise. This always occurs at critical periods in the annual cycle, particularly during sowing, when herds are late in leaving agricultural lands and during harvests, when they return too early. Clashes occur when agricultural activities hinder the movement of herds and cut off their access to water or pastures (Shetuna \& Usman, 2008, p. 65).

Conflict notifies the society that serious problems exist that are not being handled by the traditional organization. It forces the recognition of those problems and encourages the development of new solution(s) to them. In this way, it allows people to express important issues and produce certain new creative ideas; they realize and handle tensions (Abubakar, 2012, p. 55)

Whenever and wherever handled properly, conflicts can strengthen relationships, they can help groups and organizations to re-evaluate and clarify goals and missions, and they can also initiate social change to climate inequalities and injustice. But perhaps, more familiar is the negative side of conflict. Heated exchange spirals out of control, resulting in frustration, tension and hard feelings, and ultimately more conflicts. Thus, conflict is ubiquitous in the human society. Olabode and Ajibide (2010, p. 44) observed average increase in global war and identified it as predominant in the third world countries, which Nigeria is a part. The intensity and variation of the conflicts in these parts of the world depend on the actors, nature and type of the resource user groups.

Farmers and cattle rearers are known to have lived harmoniously over the years and enjoyed a mutual symbiotic relationship which was very beneficial to the two groups. The cattle rearers have often paid to graze on farmlands after harvest or in exchange for cow milk or other dairy products, while the cow droppings have often enriched the farmlands with manure. However, increasing human and animal preparations have led to the shortage of cropland and grazing land, thereby resulting in competition over valuable land resources. These increased competitions over land have resulted in encroachment of farmlands into grazing reserves and cattle routes.

The cattle rearers have oftentimes intentionally or unintentionally allowed their cattle to graze on crop lands, thereby destroying the crops before harvest. This development has brought about conflicts between the cattle herders and crop farmers.

The conflict which started gradually and was often mediated by local community authorities dimension the traditional conflict resolution mechanism that has helped resolve all forms of conflict between farmers and cattle herders in the past has pointed in recent times. This is mainly as a result of increasing distrust and suspicion among the two groups.

Today, the conflict has spread over wide geographical areas on the continents of Africa's Nigeria, and Taraba State in particular. Taraba state is one of the states in Nigeria that have been greatly affected by conflicts between crop farmers and cattle herders. It has been observed that since 2007 to date, no week passes by without reported cases of conflicts between farmers and herders. These conflicts usually result in large scale destruction of lives and properties. These conflicts have been serious threats to the means of survival and livelihood. It is against this background that it became pertinent to carry out this study. 


\section{Statement of the Problem}

Food security is national security and any household head that is unable to feed his household is not deemed responsible. By extension, any nation or state unable to feed its populace cannot be said to be responsible. Besides, recent estimates have put the number of hungry people in Nigeria as over 52 million, which is about $30 \%$ of the country's total population of roughly 200 million; of this figure, 52\% live under the poverty line (Ajayeoba, 2010:23).

These are matters of grave concern largely because Taraba State, which shares a greater part of the 52\%, was self-sufficient in food production and was indeed the food basket of the nation, as foods were obtained from this state to other states, especially the South-South and South East.

Things changed dramatically for the worse following farmers-herdsmen conflicts. Resource competition-driven conflicts between farmers and herdsmen have become occurrences in many parts of Nigeria. Abbas (2012, p. 12) and Adisa (2012, p. 78) observed that, the resource competition-driven conflicts between the two agricultural land user groups often turned into serious overt and covert hostilities and social friction in many parts of Nigeria.

Land, as a major factor of production, is increasingly declining in fertility while population is rapidly increasing at a tremendous rate of about $2.5 \%$ in the midst of declining fortune of agricultural production (World Bank, 2001, p. 103). However, the current dimension of the herders-farmers conflict is associated with the aggressive use of guns and sophisticated weapons by Udenwa and Bokoloji herders (Adeboye, 2014, p. 89).

Conflict between farmers and herdsmen has continued to assume a threatening dimension to human survival and economic livelihood. The incidence of serious resource conflicts for survival between the two groups has led to the loss of lives and herds, while others have experienced dwindling productivity in their crops and herds. In most of these encounters, citizens are regularly killed and the destruction or loss of property leaves an already endangered populace even poorer. The frequency and scale of these conflicts have not only become alarming but have also produced adverse consequences in the destruction of villages, settlements, crops, irrigation facilities, human and animal lives.

The Taraba State government, in the spirit of addressing herders-farmers conflicts, came up with anti-grazing law. All these were done to strengthen the relationship between the two groups, but the relationship keeps on degenerating. Over a period of four days, 17th-20th June, 2017, several farming areas on the Manbilla Plateau of Sarduma Local Government Area of Taraba State came under attack by armed herders and 732 people were killed. On January 30, 2018, herders living in the Leme Community, a village in the Membilla Plateau in Taraba State were killed in a vengeance attack.

The same occurred in Gareji Village on January 17, 2018. On April 10, 2019, a similar attack took place in Dori, Mesuma, in Gashaka Local Government of Taraba State. Various cases of conflict in Taraba between the herders and farmers involved significant variables in land resources. As pointed out, the livelihood of farmers and herders in Northern Nigeria-which Taraba is part - is threatened by decreasing access to land resources. In areas of stiff competition for grazing land and farms, the intensity of the conflict is high. Abbas (2012, p. 89) asserted that, in Taraba State for example, areas mostly affected include Ibi, Bali, Wukari and Takun local government areas among others. 
This conflict has caused loss of lives of farmers and cattle herders as well as innocent citizens. Regrettably, no study known to the researcher has been carried out on this problem confronting farmers and herders in the area of food security in Taraba State. This therefore necessitated this study with a view to ascertaining the impact of conflict between farmers and herdsmen on food stability in Taraba State.

\section{Aim and Objectives of the Study}

The aim of this study is to assess the impact of the conflict between farmers and herdsmen on food stability in Taraba State. The specific objectives of the study include:

1. To examine the extent of utilization that covers the balanced diet needs of the people of Taraba State during farmers-herders crisis.

2. To investigate food stability in the state by distinguishing between the period of chronic food insecurity and the period of food security.

3. To interrogate the extent of availability of food supply in the state by determining the level of food availability to the people during conflict between farmers and herders.

\section{Research Questions}

The study investigation rests on the following research questions:

1. How have farmers and herders helped to affect food utilization in Taraba State?

2. To what extent are the effects of farmers and herdsmen conflicts on food stability in Taraba State?

3. How have herdsmen-farmers conflicts affected the availability of food supply in Taraba State?

\section{Hypotheses}

Ho1 There is no significant relationship between farmers-herdsmen conflicts and food utilization in Taraba State.

Ho2 There is no significant relationship between farmers-herdsmen conflicts and food stability problems in Taraba State.

Ho3 There is no significant relationship between farmers-herdsmen conflicts and food availability in Taraba State.

\section{Significance of the Study}

The findings of this study will be of benefit to the farmers, herdsmen and the public. It is hoped in this respect that the findings will provide the needed information on the dynamics of food insecurity, especially on the basis of households and communities experiencing food insecurity resulting from the resource conflict between the two groups.

Besides, the findings of the study will add to existing literature on global conflicts with specific emphasis on land resources use conflicts. In this way, it will serve as a reference material for 
others who will have interest in this field of study.

Lastly, the researcher will also benefit from the findings, as it will increase his knowledge on the subject matter.

\section{LITERATURE REVIEW}

\section{Theoretical Framework}

\section{The Structural Functionalist Theory}

The structural functionalism evolved from the ideas of Emile Durkheim (1958-1971). It was concerned with how societies maintained internal stability and survived over time. It sought to explain social cohesion and stability through the concept of "solidarity". According to Durkheim, in more primitive societies, it was mechanical solidarity-everyone performing similar tasks - that held society together. Such societies tended to be segmented, having equivalent parts that were held together by shared values, common symbols or systems of exchange. In more complete societies, members perform very different tasks, giving rise to strong interdependence between individuals. Durkheim's argument that modern complex societies are held together by organic solidarity was based on the metaphor of an organism in which many parts function together for the sustenance of the whole. All social and cultural phenomena are therefore seen as being functional in the sense of working together to achieve the state of equilibrium, and are perfectly deemed to have a life of their own.

The structural-functionalism, on the other hand, emphasizes the conditions necessary for the society to remain at equilibrium or a balanced position. It stresses the need for interdependence of both the cattle herders and crop farmers on the use of common resources as well as specialized areas. There is a clear demarcation between the different types of conflict in farmers-herders relations. Hugberg (1998) in Toniah (2006) likewise made a distinction between the various types of conflict in farmers-herders relations. He differentiated between dispute among individuals and groups, conflict of interest and violent conflicts. While dispute refers to disagreement between two or more persons or groups, violent conflict involves mayhem, the destruction and killing of persons and livestock, arising from a climate. Every farming system, such as the nomadic cattle herding, has a boundary which separates it from the larger system - the environment. This boundary represents the limit in the larger system. Farmers increasingly compete with nomadic herders for farmland, pasture, water, trees and the use of rangeland in general (Ofouku \& Isife, 2009).

\section{Conceptual Framework}

\section{Resource Conflict}

Coser (1956), defined conflict as "a struggle over values and claims to glance status, power and resources in which the aims of the opponents are to neutralize, injure or eliminate their rivals. This perspective reinforced (Godswill, 2007) the idea that conflict is the pursuit of divergent interests, goals and aspirations by either individuals or groups in well-defined social and physical environments. Deutch (1973) had earlier mentioned that conflict is noticed whenever incompatible activities take place. However, Park and Burgee (1921) viewed conflict 
as a process designed to resolve divergent dualism and annihilate one of the conflict parties.

At a broad conceptual level, this definition of conflict could enable us to get a glimpse of the problems at hand in this study. Many writers used different descriptions to identify particular levels and types of conflict. For instance, Berger (2000, p. 20) described conflict as "deep rooted conflict", "intractable conflict" and "protracted social conflict respectively". In this context, conflict is violence, which Best (2009) in agreement described as unjustified use of force. This perception poses definitional problems because conflict is violence used in the garb of authority, wielded by the state against the will or desire of its citizens. Thus, a state sponsored violence is nothing but terrorism, especially if funded and controlled by those in power. This is not justifiable.

\section{Herdsmen}

Antonio and Silvia (2009) described pastoralists as people who live mostly in dry remote areas. Their livelihood depends on their intimate knowledge of the surrounding ecosystem and on the well-being of their livestock. According to them, the pastoral system takes many forms and is adapted to particular natural, political and economic environments, and the key feature that qualifies pastoralism is mobility. The term nomadic is used when mobility is high and in irregular patterns; transhumance, when there are regular back-and-forth movements between relatively fixed locations; but sedentary, for the rest. Pastoralists are people who derive more than 50 percent of their incomes from livestock and livestock products. Although the livelihood of these communities are vulnerable to climate change, shifting global markets, population growth and increased competition for land and other natural resources, pastoralism remains a viable natural resource management system and understanding its rationale, importance and dynamics is a key element in efforts to reduce poverty (Antonio \& Silvia, 2009).

According to Blench (2010), the Fulbe (another name for the Fulani) and the arable farmers among whom they move, have an interdependent relationship based on the exchange of dairy products for grain and a market for the animals that must be periodically sold to provide cash for domestic purposes, such as cloth or marriage payments. Moreover, in many regions, Fulbe management strategies depend on access to cereal crop residues, something arable farmers permit because of the perceived advantages of manure as fertilizer.

\section{Farmers}

Farmers, also called agriculturists, are persons who engage in agriculture; raising living organisms for food or raw materials. This therefore applies to people who do some combination of raising field crops, orchards, vineyards, poultry or other livestock. Based on this definition, farmers are both the herdsmen who herd or keep livestock like cattle, goats and sheep, and crop farmers. However, for the purpose of this work, farmers are the crop farmers (those who raise field crops) also called peasant farmers/subsistence cultivators.

\section{Food Stability}

Food stability is a situation that exists when all people, at all times, have physical, social and economic access to sufficient, safe and nutritious food that meets their dietary needs and food preferences for an active healthy life (FAO, 2002, p. 12). Food stability describes the temporal dimension of food and nutrition security, over the time frame which food and nutrition security is being considered. Stability is given when the supply on household level remains constant 
during the year and in the long-term.

\section{Empirical Review}

Suleiman and Afar-Furo (2010) examine the economic effects of farmers-graziers conflict in Nigeria with focus on Bauchi State. The study used survey research design and adopted multistage random sampling technique to select a total of 60 Fadama farmers from 60 Fadama users associations and a corresponding number of pastoralists, randomly from the Fadana

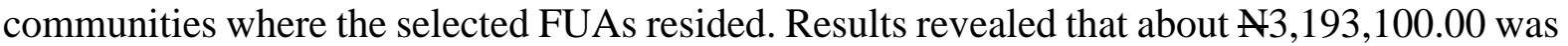
incurred from both totally damaged and partially destroyed tube wells, wash boring equipment with water pumps recording $\$ 176,415.00$. Motorcycles and bicycles accounted for $\mathrm{N} 565,254.00$ in terms of losses experienced. Comparatively, the arable farmers incurred higher $(\mathrm{N} 80,075,172)$ losses in monetary term than the pastoralists $(\mathrm{N} 7,047,013.00)$, while reduction in farm production increased poverty within and among the communities; social insecurity and inadequate food supply for the family were the major setbacks encountered in the area; interruption of education of children and reduction in healthcare provision of the family represented relatively lower proportions. The findings further showed the income of farmers $(\mathrm{N} 358,000.00)$ in the conflict area was significantly lower $(\mathrm{P}<0.05)$ than those in non-conflict areas (N437,313.00). Conclusively, the farmers-graziers conflicts have had negative effects on both the families involved and the nation, in terms of the huge resources lost, leading to food insecurity. This study is apt and very relevant to the present study. The method of analysis and findings justified the outcome of the present study. Though it differs with the present study area, nevertheless, both studies analytically assessed farmers-herdsmen conflict and its implications for food security.

Babagana (2019) studied the impact of Fulani herdsmen conflicts on food production in Cryba and Tarmuwa Local Government Areas of Yobe State, Nigeria. The study was conducted between the months of January and February, 2019. The findings of the study revealed that the majority of the respondents, including both herdsmen and farmers were subsistence workers. Few farmers however, engaged in commercial farming, regarding the causes of the conflicts, lack of grazing fields, indiscriminate bush burning and crop destruction. No significant difference was found in the perception of the herdsmen and farmers on the causes of the conflicts. The impacts of Fulani herdsmen-farmers conflicts revealed by the study include the loss of crops, reduced productivity, loss of lives, increase in prices of agricultural products and increased poverty. The review study is related to the present study in many ways. First, both studies analyzed effects of herdsmen-farmers conflicts on food production and distribution.

Sunbirly and Handeior (2018) carried out a research on the implication of Fulani HerdersBenue farmers crises on food security of Benue State of Nigeria. The study specifically examined the effects of herdsmen attacks on food availability and accessibility, towards maintaining a healthy and active life in the state. The result of the study showed that herdsmenfarmers crises have directly and indirectly affected food security in Benue State. The study is relevant to present work in many ways. Both studies engaged in assessment of the impact of herdsmen-farmers conflicts on food security. Though the method used by the previous author differs, the outcome of the study further strengthened the results of the present study.

Abuga and Omuba (2015) examined the various cases of conflicts between both groups. He employed statistical methods with descriptive variants. From the study analysis, the study noted and as well, documented a series of conflicts between the farmers and the herdsmen from 
Northern Nigeria, including some states in the Middle-Belt and the Eastern region. The study findings corroborate The Sun Newspaper (2013) reports that identified the conflict between the farmers and herdsmen in Agatu Community of Benue State-a conflict which left several people dead. In the Eastern parts of the Country, like Uzouwani (Enugu State), Ezeagiamd Umuahia (Abia State), such clashes did not go unnoticed in 2013. The Vanguard (2013) reported that the Fulani killed three people and caused significant damage to crops in Umuahia, Abia State.

The South-West region is not exempted from the conflicts between the two land-user groups. The Nation (2012) reported that armed herdsmen invaded Oke-Ako area in Ikole Local Government of Ekiti State and killed a farmer on his plot. Many of these acts also occurred in Gyramia communities of Oyo, Osun, Ondo, Kaduna, Plateau State and other parts of the Country. However, the Miyetti Allah Cattle Breeders Association-the umbrella organization of herdsmen - notes that it has lost no fewer than 60,000 cows to the crisis. In Taraba State, Conflict and Security Analysis Networks (2015) reported series of farmers-herdsmen conflicts in the state, particularly Southern and Central Taraba, including the boundaries between Taraba and Benue, Taraba and Adamawa, Taraba and Plateau, as well as the Nigeria-Cameroon border region, where thousands of farmers were displaced and many others killed.

The frequent attack on the farmers and citizens of Nigeria by herdsmen is terribly alarming. Amebovillage.com (2013) confirmed this when he averred that, previously the herdsmen were known to wreak havoc in certain communities in Nigeria, but now the rate at which they are committing these crimes has increased exponentially. The findings of the reviewed study are very much related to the current work in the sense that they established clearly that the current area of study is one of the areas affected by farmers-herdsmen conflict. The fact in the analysis above is that conflict between both groups is on the increase. They failed to discuss the impact on food crisis or security in the study areas.

Bernard et al. (2010) conducted research on possible causes of conflicts between farmers and herdsmen in Nigeria. The study used a survey design and sampled respondents with four research questions. From the analysis, the result revealed that destruction of crops by cattle and other property (irrigation equipment and infrastructure) by the pastoralists themselves are the main direct causes of conflicts cited by the farmers; whereas burning of rangelands in Fadama and blockage of stock routes and water points by crop encroachment are important direct reasons cited by the pastoralists. The result found support in Ingawa (2008) study. The later study found that the underlying causes of farmers-herdsmen conflict in Nigeria include changing resource access rights, whereby traditional access rights to communal grazing and water resources are being obstructed by the individual tenureship of arable farmers. This is particularly severe on the traditional trek routes, which become favorite cropping sites because of their better soil fertility resulting from the concentration of animal manure from the trekking herds in these areas. Within the Fadama areas, this is exacerbated by the fragmented nature of the crop plots, which makes prevention of animals straying in the crop plots difficult. 


\section{METHODOLOGY}

This study was a descriptive survey carried out in Taraba State. The population of the study consisted of all residents of Taraba. According to the National Population Commission (2006), there are about 2,300,736 people residing in Taraba State; this constituted the population of this study. The sample size for this study was $400(\mathrm{n}=400)$. A multistage sampling technique was adopted in selecting the sample for the study. Firstly, stratified sampling was used to determine the senatorial districts to be sampled, then simple random sampling technique was utilized in selecting the local government areas from each of the sampled senatorial districts for the study. Finally, 3 communities were purposively selected from the sampled local governments areas to select respondents for the study.

Data for the study was collected from both primary and secondary sources. Primary data were obtained through a field survey, using a structured questionnaire. A standardized questionnaire titled, "Conflict between Farmers and Herdsmen on Food Stability in Taraba State Questionnaire" was used as the instrument of the study. The instrument consisted of two sections-A and B. Section A elicited socio-demographic information from the respondents, while section B, information on the impact of the farmers-herdsmen conflict on food stability in Taraba State. A total of 400 copies of questionnaires were administered to the respondents. While 385 copies were completed and retrieved, thirteen (13) copies of the questionnaires were not returned by the respondents.

Adopted questionnaire was subjected to face and content validation. The instruments were validated by the research supervisor and three experts from the Department of Political Science, Rivers State University. It was subjected to modification for the current study. To ensure the reliability of the instrument, the Cronbach's Alpha Coefficient was utilized. After computation, the reliability coefficient for the instrument yielded 0.04. This is considered sensitive and good enough for the study. Data was collected and analyzed using the statistical package for social science (SPSS) version 23.0. Descriptive statistical tools were utilized to analyze the socio-demographic factors of respondents and answer the research questions, whilst inferential statistical tool—such as the Pearson Product Moment Correlation coefficient at 0.05 level of significance — was employed to test the hypothesis.

\section{RESULTS AND DISCUSSION OF FINDINGS}

\section{SECTION A: Socio-Demographic Factors of Respondents}

\begin{tabular}{lll} 
Socio-demographic Characteristics & Frequency $(\mathbf{F})$ & Percentage \% \\
\hline Gender & & \\
Male & 200 & 51.0 \\
Female & 185 & 49.0 \\
Total & $\mathbf{3 8 5}$ & $\mathbf{1 0 0 . 0}$ \\
Age & & \\
$20-29$ & 40 & 10.0 \\
$30-39$ & 86 & 22.0 \\
$40-49$ & 97 & 25.0 \\
$50-59$ & 106 & 28.0 \\
60-Above & 56 & 5.0
\end{tabular}


Total

Marital Status

Married

Single

Widowed

Total

Occupation

Farming

Cattle rearing

Farming and cattle rearing

Total

Educational Status

No education

Primary

Secondary

Tertiary

Quranic education

Total
385

100.0

305

79.0

35

45

385

200

85

100

385

29

56

100

100

100

385
12.0

12.0

100.0

51.9

22

25.9

100.0

5

14.5

25.9

25.9

25.9

100

\section{Research Questions}

Research Question 1: How have farmers and herders helped affect food utilization in Taraba State?

Table 2 Impact of Farmers and Herders on Food Utilization in Taraba

\begin{tabular}{|c|c|c|c|c|c|c|c|c|}
\hline $\mathbf{S N}$ & Items & SA (\%) & $\mathrm{A}(\%)$ & $\mathrm{D}(\%)$ & SD (\%) & Mean & SD & Decision \\
\hline 1 & $\begin{array}{l}\text { The clash between farmers } \\
\text { and herdsmen has not } \\
\text { greatly impacted on food } \\
\text { stability in Taraba State. }\end{array}$ & $\begin{array}{c}68 \\
(17.7)\end{array}$ & $\begin{array}{c}18 \\
(4.7)\end{array}$ & $\begin{array}{c}159 \\
(41.3)\end{array}$ & $\begin{array}{c}140 \\
(36.4)\end{array}$ & 2.04 & \pm 1.06 & Disagreed \\
\hline 2 & $\begin{array}{l}\text { The farmers and herdsmen } \\
\text { conflict has greatly affected } \\
\text { food consumption in Taraba } \\
\text { State. }\end{array}$ & $\begin{array}{c}141 \\
(36.6)\end{array}$ & $\begin{array}{c}114 \\
(29.6)\end{array}$ & $\begin{array}{c}48 \\
(12.5)\end{array}$ & $\begin{array}{c}82 \\
(21.3)\end{array}$ & 2.82 & \pm 1.15 & Agreed \\
\hline 3 & $\begin{array}{l}\text { The dispute between } \\
\text { farmers and herders is so } \\
\text { much that food utilization } \\
\text { in Taraba State is affected. } \\
\text { Grand mean }\end{array}$ & $\begin{array}{c}204 \\
(53.0)\end{array}$ & $\begin{array}{c}89 \\
(23.1)\end{array}$ & $28(7.3)$ & $\begin{array}{c}64 \\
(16.6)\end{array}$ & 3.12 & \pm 1.12 & Agreed \\
\hline
\end{tabular}

Table 2 displays the responses derived from the respondents in Taraba State on the impact of farmers and herders on food utilization in Taraba. From the table, it was observed that the respondents agreed to most of the items enumerated. Based on the responses, a grand mean of 2.72 was derived, which is greater than the criterion mean, 2.5. This entails that the conflict between farmers and herders has impacted food utilization in Taraba. The highest proportion 
of each of the items showed that $141(36.6 \%)$ of the respondents strongly agreed to the item which says that the farmers-herdsmen conflict has greatly affected food consumption in Taraba State. Also, $204(53.0 \%)$ of the respondents strongly agreed that the dispute between farmers and herders is so much that food utilization in Taraba State is affected.

Research Question 2: To what extent is the effect of farmers-herdsmen conflict on food stability in Taraba State?

Table 3: Effect of Farmers-Herdsmen Conflict on Food Stability in Taraba State

\begin{tabular}{|c|c|c|c|c|c|c|c|c|}
\hline$\overline{\mathbf{S N}}$ & Items & SA (\%) & $\mathrm{A}(\%)$ & D (\%) & SD (\%) & Mean & SD & Decision \\
\hline 1 & $\begin{array}{l}\text { The conflict between } \\
\text { farmers and herders has } \\
\text { not greatly impacted on } \\
\text { food stability in Taraba } \\
\text { State. }\end{array}$ & $\begin{array}{c}48 \\
(12.5)\end{array}$ & $\begin{array}{c}48 \\
(12.5)\end{array}$ & $\begin{array}{c}131 \\
(34.0)\end{array}$ & $\begin{array}{c}158 \\
(41.0)\end{array}$ & 1.96 & \pm 1.02 & Disagreed \\
\hline 2 & $\begin{array}{l}\text { Increase in food prices in } \\
\text { Taraba State is being } \\
\text { caused by farmers-herders } \\
\text { conflict. }\end{array}$ & $\begin{array}{c}127 \\
(31.2)\end{array}$ & $\begin{array}{c}152 \\
(39.5)\end{array}$ & $24(6.2)$ & $\begin{array}{c}82 \\
(21.3)\end{array}$ & 2.84 & \pm 1.02 & Agreed \\
\hline 3 & $\begin{array}{l}\text { Looting of stored foods } \\
\text { during farmers-herders } \\
\text { conflict is responsible for } \\
\text { food instability in Taraba } \\
\text { State. }\end{array}$ & $\begin{array}{c}97 \\
(25.2)\end{array}$ & $\begin{array}{c}151 \\
(39.2)\end{array}$ & $52(13.5)$ & $\begin{array}{c}85 \\
(22.1)\end{array}$ & 2.68 & \pm 1.08 & Agreed \\
\hline
\end{tabular}

Table 3 displays the responses derived from the respondents in Taraba State on the effect of farmers-herdsmen conflict on food stability in Taraba State. From the table, it was observed that the respondents disagreed with most of the items enumerated. Based on the responses, a grand mean of 2.49 was derived which is lesser than the criterion mean $=2.5$. Thus, this insinuates that the conflicts between farmers and herdsmen have impacted food stability in Taraba State. The highest proportion of each of the items showed that 127 (31.2\%) of the respondents strongly agreed that increase in food price in Taraba State is being caused by farmers-herders conflict. Also, $152(39.2 \%)$ of the respondents agreed that looting of stored foods during farmers-herders conflict is responsible for food instability in Taraba State.

Research Question 3: How has herdsmen-farmers conflict affected availability of food supply in Taraba State? 
Table 4: Impact of Herdsmen-Farmers Conflict on Availability of Food Supply in Taraba State

\begin{tabular}{|c|c|c|c|c|c|c|c|c|}
\hline $\mathbf{S N}$ & Items & SA (\%) & $A(\%)$ & D (\%) & SD (\%) & Mean & SD & Decision \\
\hline 1 & $\begin{array}{l}\text { The violent struggle over } \\
\text { land and water resources } \\
\text { between farmers and } \\
\text { herders is not responsible } \\
\text { for food security in Taraba } \\
\text { State. }\end{array}$ & $\begin{array}{l}47 \\
(12.2)\end{array}$ & $\begin{array}{l}33 \\
(8.6)\end{array}$ & $\begin{array}{l}128 \\
(33.2)\end{array}$ & $\begin{array}{l}177 \\
(46.0)\end{array}$ & 2.04 & \pm 1.06 & Disagreed \\
\hline 2 & $\begin{array}{l}\text { Farmers-herders conflict } \\
\text { affects availability of food } \\
\text { diversity (vegetables, fruits } \\
\text { and cereals) in Taraba State. }\end{array}$ & $\begin{array}{l}109 \\
(28.3)\end{array}$ & $\begin{array}{l}150 \\
(39.0)\end{array}$ & $\begin{array}{l}69 \\
(17.9)\end{array}$ & $57(14.8)$ & 2.82 & \pm 1.15 & Agreed \\
\hline 3 & $\begin{array}{l}\text { The conflict between } \\
\text { farmers and herders has } \\
\text { tremendously affected } \\
\text { sufficient food supply in } \\
\text { Taraba State. }\end{array}$ & $\begin{array}{l}189 \\
(49.1)\end{array}$ & $\begin{array}{l}127 \\
(33.0)\end{array}$ & $\begin{array}{l}62 \\
(16.1)\end{array}$ & $7(1.8)$ & 3.12 & \pm 1.12 & Agreed \\
\hline & Grand mean & & & & & 2.66 & \pm 1.11 & Agreed \\
\hline
\end{tabular}

Table 4 displays the responses derived from the respondents in Taraba State on the impact of herdsmen-farmers conflict on availability of food supply in Taraba State. From the table, it was observed that the respondents agreed to most of the items enumerated. Based on the responses, a grand mean of 2.66 was derived, which is greater than the criterion mean, 2.5. This entails that conflict between farmers and herdsmen has damagingly affected availability of food supply in Taraba State between 2007 and 2018. The highest proportion of each of the items showed that $189(49.1 \%)$ of the respondents strongly agreed that the conflict between farmers and herders has tremendously affected sufficient food supply in Taraba State. Also, 109 $(27.3 \%)$ of the respondents strongly agreed that the conflict between farmers and herders disrupts the marketing of foodstuffs and has led to the unavailability of food in Taraba State.

\section{Testing of Hypotheses}

Hypothesis 1: There is no significant relationship between farmers-herdsmen conflict and food utilization in Taraba State. 
Table 5: Relationship between Farmers-Herdsmen Conflict and Food Utilization in Taraba State

\begin{tabular}{llrrr}
\hline & & $\begin{array}{c}\text { Correlations } \\
\text { Farmers-herdsmen } \\
\text { conflict }\end{array}$ & Food utilization & Decision \\
\hline Farmers- & Pearson Correlation & 1 & -.315 & Rejected \\
herdsmen & Sig. (2-tailed) & 385 & .000 & \\
conflict & $\mathrm{N}$ & -.315 & 385 & \\
Food & Pearson Correlation & .000 & 1 & \\
utilization & Sig. (2-tailed) & 385 & 385 & \\
& $\mathrm{~N}$ & & &
\end{tabular}

$* S=$ Significant $p<0.05$

The result in table 5 shows the relationship between farmers-herdsmen conflict and food utilization in Taraba State. Pearson correlation coefficient demonstrates a weak negative relationship between the two variables, $\mathrm{r}=-.315$, indicating that there exists a weak negative relationship between farmers-herdsmen conflict and food utilization in Taraba State. Furthermore, the null hypothesis which states that there is no significant relationship between farmers-herdsmen conflicts and food utilization in Taraba State was rejected and the alternate hypothesis upheld $[(\mathrm{P}=.000) \mathrm{p}<0.05]$.

Hypothesis 2: There is no significant relationship between farmers-herdsmen conflicts and food stability problems in Taraba State.

Table 6: Relationship between Farmers-Herdsmen Conflict and Food Stability Problems in Taraba State

\begin{tabular}{llrrr}
\hline & \multicolumn{2}{c}{$\begin{array}{c}\text { Correlations } \\
\text { Farmers-herdsmen } \\
\text { conflict }\end{array}$} & Food stability & Decision \\
\hline Farmers- & Pearson Correlation & 1 & .291 & Rejected \\
herdsmen & Sig. (2-tailed) & & .000 & \\
conflict & N & 385 & 385 & \\
Food & Pearson Correlation & .291 & 1 & \\
stability & Sig. (2-tailed) & .000 & 385 & \\
& N & 385 & 3 & \\
\end{tabular}

$* S=$ Significant $p<0.05$

The result in table 6 shows the relationship between farmers-herdsmen conflict and food stability problems in Taraba State. Pearson correlation coefficient demonstrates a weak positive relationship between the two variables, $r=-.291$, indicating that there exists a weak positive relationship between farmers-herdsmen conflict and food stability problems in Taraba State. Furthermore, the null hypothesis which states that there is no significant relationship between farmers-herdsmen conflicts and food stability problems in Taraba State was rejected and the alternate hypothesis upheld $[(\mathrm{P}=.000) \mathrm{p}<0.05]$. 
Hypothesis 3: There is no significant relationship between farmers-herdsmen conflicts and food availability in Taraba State.

Table 7: Relationship between Farmers-Herdsmen Conflict and Food Availability in Taraba State

\begin{tabular}{llrrr}
\hline & & $\begin{array}{c}\text { Correlations } \\
\text { Farmers-herdsmen } \\
\text { conflict }\end{array}$ & Food availability & Decision \\
\hline Farmers- & Pearson Correlation & 1 & -.141 & Rejected \\
herdsmen & Sig. (2-tailed) & & .006 & \\
conflict & $\mathrm{N}$ & 385 & 385 & \\
Food & Pearson Correlation & -.141 & 1 & \\
availability & Sig. (2-tailed) & .006 & 385 & \\
& $\mathrm{~N}$ & 385 & 38 & \\
\hline
\end{tabular}

$* S=$ Significant $p<0.05$

The result from table 7 shows the relationship between farmers-herdsmen conflict and food availability in Taraba State. Pearson correlation coefficient demonstrates a weak negative relationship between the two variables, $\mathrm{r}=-.141$, indicating that there exists a weak negative relationship between farmers-herdsmen conflict and food availability in Taraba State. Furthermore, the null hypothesis which states that there is no significant relationship between farmers-herdsmen conflicts and food availability in Taraba State was rejected and the alternate hypothesis upheld $[(\mathrm{P}=.006) \mathrm{p}<0.05]$.

\section{CONCLUSION}

One of the major threats to peaceful coexistence, according to findings from group discussions with some respondents, is the damage caused by the influx of Udawa and Bukoloji cattle herders, who usually come through the Niger/Nigeria border. These types of herders do not recognize the existence of any boundary in terms of their grazing; they come in hundreds and are usually fully armed with modern guns. They move with thousands of cattle sparing no farm. At the same time, a mix of weather-related factors push farmers to cultivate more lands each year, leaving the herders fewer places to water and graze their stock. The resulting contests have been responsible for the deaths of several hundreds of farmers and the attendant threats to food security.

\section{RECOMMENDATIONS}

Based on the findings of the study, the following recommendations are suggested:

1. The government should invest in rural infrastructure to improve access to the food market to support stability.

2. Government should create farm settlements and farm tools for farmers.

3. Strengthen security arrangement for herders and farming communities. This will require 
that governments and security agencies sustain campaigns against crop damages, improve early morning systems, maintain operational readiness of rural-based security men, and encourage documentation and collaboration with local authorities.

4. Resettlement of displaced farmers and herders to enable them resume food production.

5. Government should pay special attention to ways of promoting greater food utilization and accountability through the establishment of a special inclusion, to maintain food value chains and to supply friendly information on food production and consumption, in order to increase food security.

6. Government should establish sustainable cattle ranching in different parts of Taraba State and encourage medium techniques in cattle rearing.

\section{REFERENCES}

Abbas, I. M. (2012). No retreat, no surrender conflict for survival between pastoralists and farmers in northern Nigeria. European Science Journal 8(1): 331 - 349.

Abubakar, M. B. (2012). A sociological assessment of nomadic pastoralists and sedentary farmers conflict in Katsina State (2007 - 2011). (Unpublished M.Sc Thesis), Ahmadu Bello University, Zaria.

ACLED (2015). Armed Conflict Location and Event Data Project. http://www.acleddata.com /data/version-4-data-1997-2013.

Adeboye, R. O. (2014). Land, agriculture and food security in Nigeria. $3^{\text {rd }}$ Faculty Lecture, Faculty of Agriculture, University of Ilorin, Illorin.

Adisa, R. S. (2012). Land use conflict between farmers and herdsmen: Implications for agricultural and rural development, Department of Agricultural Extension and Rural Development, University of Ilorin, Ilorin, Nigeria.

Ajayeoba, A. (2010). Concerning food security in Nigeria. West Africa Insight. pp 1.

Amebovillage.com (2013). 9 feared dead as Fulani herdsmen attack Commercial bus in Benue. Retrieved on September 3, 2013.http://amebovillage.com/9-feared-dead-asfulani-herdsmen-attack-commercialbus-in-benue.

Antonio, O. \& Silvia, S. (2009). Livestock and pastoralists. Livestock thematic Papers: Tools for Project Design, International Fund for Agricultural Development. www.ifad.org/irkm/index.htm

Babagana. C. (2019). "Democratization of disempowerment in Africa". Centre for Advanced Social Sciences. Malthouse Press.

Berger, R. (2003). Conflict over Natural Resources among Pastoralists in Northern Kenya: A Look at Recent Initiatives in Conflict Resolution. Journal of International

Development, 15(2), 245 - 257.

Bernard, C., Bonnet, B., \& Guivert, B. (2010). Demand for farm animal products in Nigeria: An opportunity for Sahel countries? Grain de Sel, 51; 1415.

Best, P. A. (2009). "The role of higher education in national integration in Nigeria." In Higher Education, 19, 293-305

Blench, R. (2010). Conflict between cattle herders and cultivators in Nigeria. Kay Wasiamson Educational Foundation.

Coser, L. A. (2003). Continuation in the study of social conflict. Macmillan Publishers. 
Deutch, M. (1973). Development communication: Principles and practice. Stirling Holden. Ekong, E. E. (2003). An introduction to rural sociology. Dove Educational Publishers. FAO (2002). Pastoralism in sub-saharan Africa: Know its advantages, understand its challenges, act for its sustainability. http://www.fao.org/fileadmin/template.

Fulger, B. (2009). Content analysis in communication research. The Free Press.

Godswill, R. (2007). Pastoralism in the new millennium. Food and Agriculture Organisation, Rome.

Hugberg, E. (1998). Recurrent conflicts among migrant Fulani herdsmen and indigenous communities of southern Nigeria. A review of literature, International Journal of Health and Social Inquiry. 3(1), 22-25.

Ingawa, S. A. (2008). Farmer-pastoralists conflict in the core states of National Fadama Development Project, Federal Agricultural Unit (FACU).

Jeony, H. (2008). Understanding conflict and conflict analysis. Sage Publication.

Momale, S. B. (2003). Resource use conflicts in agricultural and pastoralist areas of Nigeria. Nigeria Land Network.

Ofuoku, A. U., \& Isife, B. L. (2009). Causes, effects and resolution of farmers-nomadic cattle herders conflicts in Delta State, Nigeria. International Journal of Sociology and Anthropology, 1(2) 49.

Olabode, A. D. \& Ajibade, L. T. (2010). Environment induced Conflict and Sustainable Development: A Case of Fulani-Farmers' Conflict in Oke-EroLgos, Kwara State, Nigeria. Journal of Sustainable Development in Africa. 12(5), 259 - 273.

Shetima, A. G., \& Usman T. A. (2008). Farmers-Pastoralist Conflict in West Africa: Exploring the Causes and Consequences. Information Society and Justice 3(1), 163 184.

Suleiman, S.A. (2010). Introduction to Political Science Research. Nissi Books.

Toniah, U. M. (2006). Sociology, culture and social problems: Essays and insights Lagos. Institute of Communication and Entrepreneurship Development.

World Bank. (2001). "The peoples of Nigeria." Journal of African Affairs. 1 (262), 23-32. 